\title{
A Chronological Study of the False Door Concept
}

\author{
Doha Mohamed Sami Abdel Hamid
}

Seyouf Higher Institute for Tourism, Hotels, and Computer- Alexandria

\begin{abstract}
In Ancient Egypt, the false door was thought to be a threshold between the world of mortals and that of deities; where spirits lived. The deity could interact with the world of the living either by passing through the false door or receiving offerings through. False doors are often one of the striking elements within tomb complexes; they were usually located on the western wall of the chapel's offering room; known as an offering chamber. This was usually the rear wall of the chapel or the mortuary temple. False door was frequently of limestone; however, ones of the elite with close connections to the king were of pink granite. Sometimes pink granite was imitated by painting a limestone false-door stela a mottled pink. This paper aims to discussing the non-royal false door concept, and compares its role from the old Kingdom and till the end of the New Kingdom. It analyzes three non-royal false doors; chronologically dating from the Old Kingdom, Middle Kingdom and New Kingdom.
\end{abstract}

Keywords: False door, Non-royal, Limestone, Pink granite, Chapel, Mortuary temple

\section{Introduction}

False door is one of the common elements within Egyptian tomb complexes. Moreover, it is one of the chief

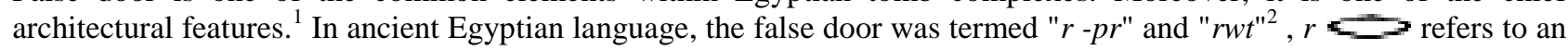
opening $^{3}$, and $p r(\sqsubset \neg$ refers to the house. Howeover, the whole name " $r$-pr" the second name "rwt" gate to the underworld. Moreover, it was termed " $K_{3}$ door", 7 because the " $K a$ " or the deceased's spirit was believed to have the ability to pass through. Therefore, it was the link between the living world and the netherworld for the deceased's $k a$ to obtain offering.

The living was convinced he could communicate with the deceased's $k a$ through the false door. ${ }^{8}$ The deceased was presumed to move upwards and emerge through. ${ }^{9}$ The false door was typically occupying the west wall of the tomb's main room, known as the offering chamber. Many typological changes affected the false door; the chief elements were nearly always present. The real door is in the center, with a drum, imitating a rolled-up reed mat; above the opening; a panel above the door with a depiction of the deceased seated at a well-supplied offering table, and a single or several sets of doorjambs inscribed with offering formulae, besides, the names and titles of the deceased. ${ }^{10}$

Below these inscriptions; there is usually a standing representation of the tomb owner. He often holds a staff, a scepter, and dressed in clothes express his status in life. ${ }^{11}$ On many false-door stelae, a so-called torus molding; a rounded edge imitating a bundle of reeds tied together with ropes, is added around the door's frame, and above; is the hollow cavetto cornice decorated with stylized palm leaves. ${ }^{12}$

\section{The role of the false door}

The false door had two major religious roles; to connect the deceased's spirit to interact with the living world, and to receive offerings. ${ }^{13}$ Offerings were deposited before the false door; a water basin and offering tables were put before the equipment to perform an offering ritual. ${ }^{14}$

An inscribed gravestone stele was located in the non-royal tombs from the Early Dynastic Period as an offering stele. By the Old Kingdom, this stone stele had been developed into a form of a false door. ${ }^{15}$ This false door stele indicates how the Ancient Egyptian regarded the relationship between the living creatures and the dead, and the physical requirements for each. ${ }^{16}$ The spiritual entities needed physical prompts to interact with the living world, while the livings needed places for this interaction. ${ }^{17}$ Due to this concept, the dead and the living creatures communicate with each other through funerary practices and texts, ${ }^{18}$ where rituals were performed, to enable the deceased partaking the set on the offering table. ${ }^{19}$

\section{The offering formula}

The principal element of the false door was the offering formula inscribed on its lintel; God Anubis was invoked in the offering formulaes inscribed in the oldest mastabas: ${ }^{20}$ that the king gives, and Anubis Lord of sacred land'. ${ }^{21}$ The name of God Osiris does not occur in the offering formulae until the late fourth Dynasty, ${ }^{22}$ or the bigining of the Fifth. ${ }^{23}$ 
of Djedu'.

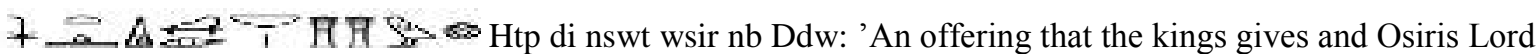

Since the beginning of the Old Kingdom, the offering formula has been present on the false door's Lower lintel. Starting the Middle Kingdom; it was increasingly placed on the door jambs and the panel. ${ }^{24}$ The offering formula "Htp di nswt", may have to be regarded as an abbreviation of the formula for food offerings, "Htp di inpw" being a separate formula where the name of God Anubis is inscribed to invoke the deceased a good burial, a happy pass to the other world, and so forth. ${ }^{25}$

In addition, the epithets of other Gods occurred in offerings formula

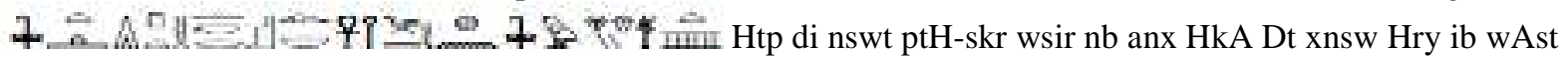

A gift which the King gives, before Ptah-Sokar, Osiris, and Khonsu Lord of Thebes. ${ }^{26}$

\section{False door aspects during the Old Kingdom}

During the Old Kingdom, false-door was the chief feature of all forms and types of mastaba chapels. ${ }^{27}$ It was constructed of crude-brick and wood, or of small stone blocks. With the eve of the fourth Dynasty; it became usual to carve the false-door in a monolith, which formed the back of the niche. While the deep niche's sides were made of two other stone set upright. ${ }^{28}$ There were two main types of false door during the Old Kingdom; the palace façade false door or "serekh type" (Fig.1), and the normal false door (Fig.2). ${ }^{29}$

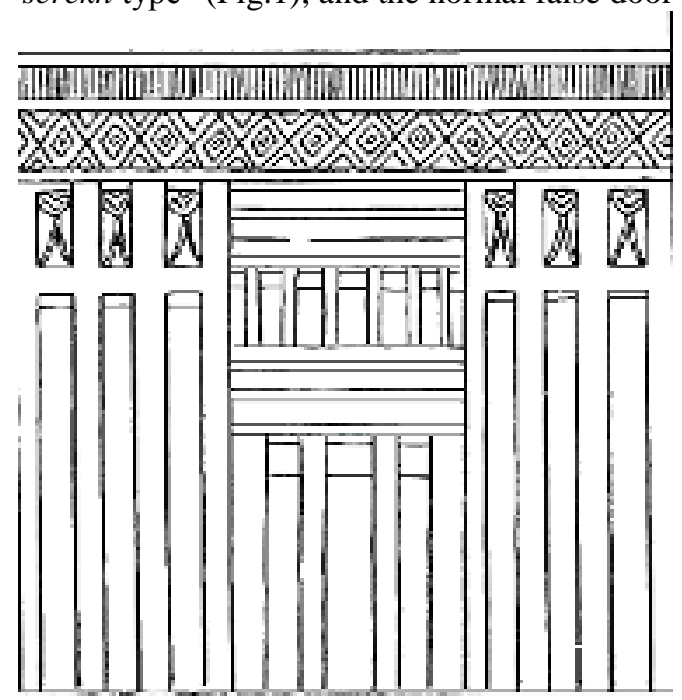

Fig. (1) LÄ (V), "Scheintür", col. 564

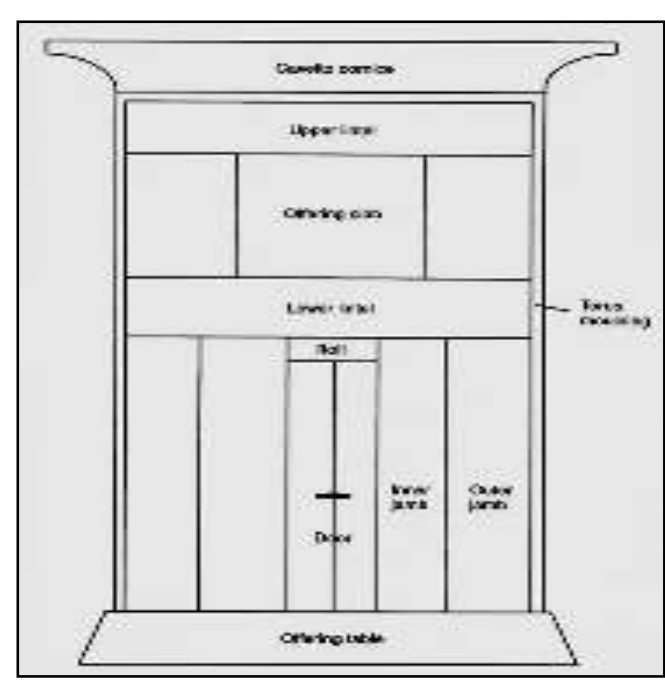

Fig. (2) www.ancient-egypt.co.uk/.../egyptian_religious_art.pdf

During the Old kingdom, the false door design was divided into several parts, ${ }^{30}$ as shown in Table (1). The chief part was the "offering slab", where the deceased in most cases was seated at an offering table, ${ }^{31}$ or was simply inscribed with the offering formulae. ${ }^{32}$

\begin{tabular}{|l|l|}
\hline Name & Usage \\
\hline The Cavetto cornice & Palms decoration \\
\hline The upper lintel: & The owner representation \\
\hline Offering slab(panel) & $\begin{array}{l}\text {-Tomb owner alone at the offering table } \\
\text {-Tomb owner with another person } \\
\text {-Offering Formulae }\end{array}$ \\
\hline Lower lintel: & The owner representation \\
\hline Roll: & Name of the tomb owner \\
\hline Door or(niche): & Offering formulae \\
\hline Inner jamb: & Texts or large figure of the deceased \\
\hline Outer jamb: & Texts or large figure of the deceased \\
\hline Torus moulding: & Type of decoration \\
\hline
\end{tabular}

Table (1), During the Old Kingdom; main parts of the false door: Takenoshita.J. (2011),"When the Living met the Dead: The Social Functions of False Doors in Non-Royal Funerary Culture with references to examples from the First Intermediate Period and Middle Kingdom”,p.15. 
The earliest false doors were mostly without the cavetto cornice, and the Torus moulding. ${ }^{33}$ The Presence or absence of those two features was the obvious dissimilarity between several false doors. ${ }^{34}$ The fourth Dynasty falsedoor rose above the surface of the space, where it occurs like a separate stone set in the structure. ${ }^{35}$ Using unequal length jambs with variant sized figures of the deceased began during this Dynasty, and continued at least to the middle of the fifth. ${ }^{36}$ At that time, the cornice and torus molding began to appear on the highest officials doors. These led to the development of even long inscriptions and small figures of the deceased on jambs. ${ }^{37}$ This latter feature is sometimes found later in the fifth dynasty with neither the cornice nor the torus. ${ }^{38}$ During the Sixth Dynasty, the false door show changes from the above form: Two or three jambs are used, but they tend to be narrow with only one column of inscription with a similar disposition of texts and equal figures of the deceased. ${ }^{39} \mathrm{~A}$ false door set within a recess in the west wall is a monolithic limestone door with a torus molding, and surmounted by a cavetto cornice. Towards the end of the Old Kingdom; this was the standard type for false doors, ${ }^{40}$ this trend is towards a simplification form of the door. ${ }^{41}$ Another renovation at the end of the sixth dynasty was the appearance of the" $w \underline{d} 3 . t$ "eyes" on the decorated false doors. $^{42}$

False door of the scribe Redines ${ }^{43}$ according to Brunner and Wreszinski; it is dated to the fifth dynasty, while most studies dated it to the sixth dynasty. ${ }^{44}$ It was part of his mastaba on the western side of the Great Pyramid at Giza. ${ }^{45}$ This was among the excavations held by the Harvard University-Museum of Fine Arts Expedition, and shipped to Museum of Fine Arts in Boston on $1921^{46}$.

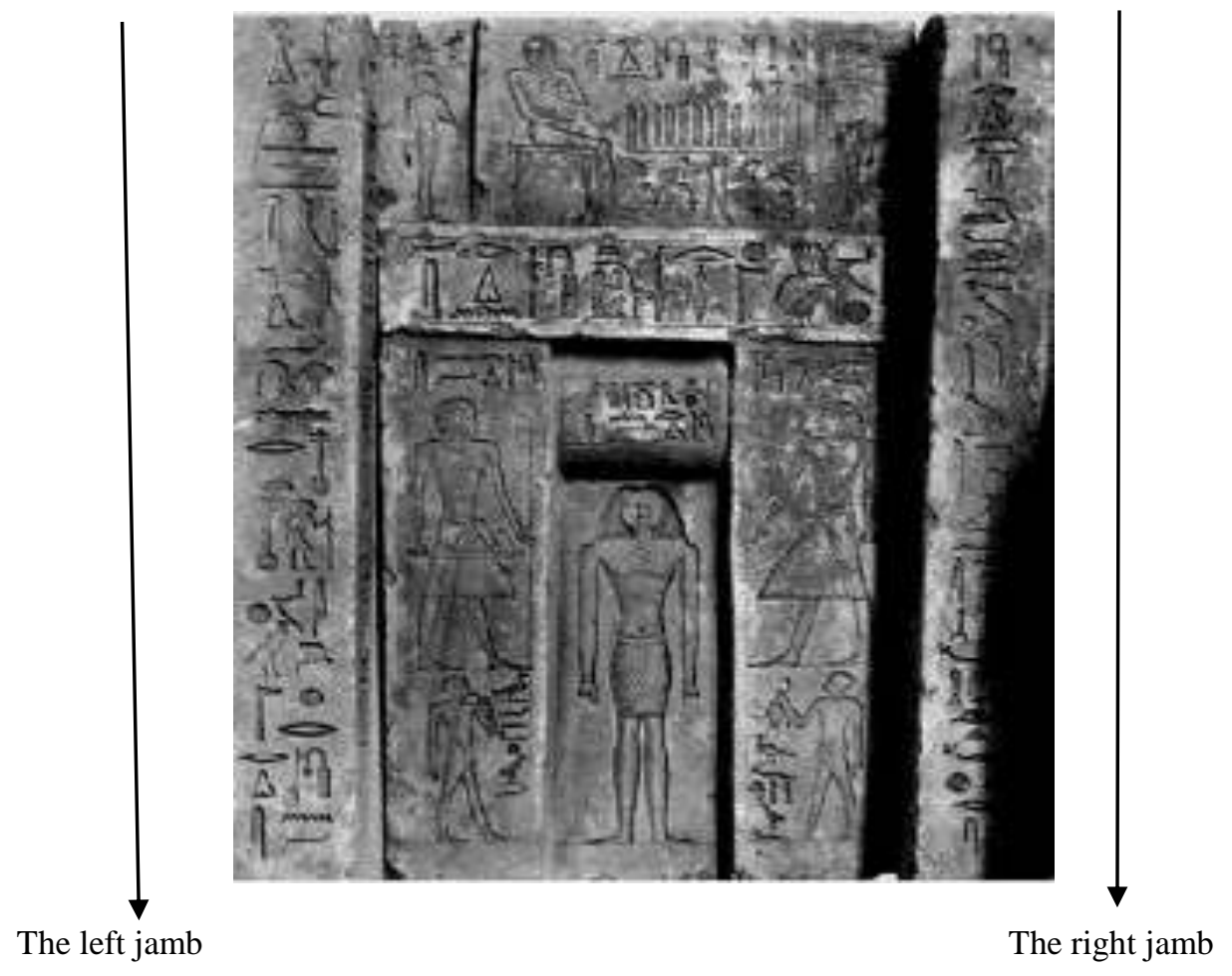

Fig.(3)False Door of Redi-nes, and Texts on the left Jamb: Der Manuelian.P(1994),The Giza Mastaba Niche and full frontal figure of Redi-nes in the Museum of fine arts, Boston ,SAOC(55), The Oriental Institute of the University of Chicago,p.61-p.63.

The false door was discovered at the far end of the tomb's western wall. ${ }^{47}$ Picking this limestone false door as a case study of the Old Kingdom, is due to its rare representation of the tomb-owner scribe and royal -priest in a full frontal pose. Besides, the unusual feet which splayed outward in the door's central niche. It was carved in sunken-relief, its unique frontal pose creates a more direct confront with the viewer, where the tomb owner emerges from the land of the dead and accessing the land of the living. ${ }^{48}$ According to Smith; this frontal figure represents an imitation of the false doors which have a statue standing in the inner niche, as though issuing from the tomb. ${ }^{49}$ While Schäfer noted this frontal figure serve as a substitute for a semi-sculpture.

On the top of the door, a scene showing the scribe Rediness seated before a table of fourteen offering loaves, below the table are listed offerings signs for bulls, fowel, geese and oryxes.

The left jamb inscriptions:

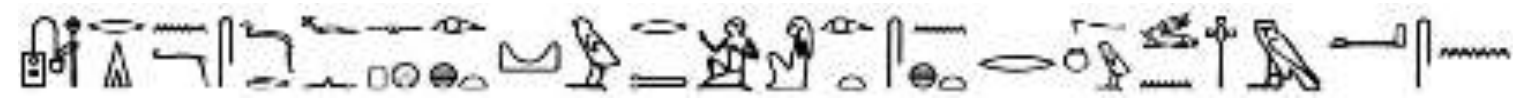


s.s Rdi-ns dd.f $n z p$ ir. (i) bt dw [r] rmt.t

ir.ry.sn bi $r$ nw wn. $<f>n d(. w) m-\bullet s n$

"Scribe Rediness says: Never did I do any evil thing against people, those who will do something against this, it shall be protected from them."

The right jamb inscriptions:

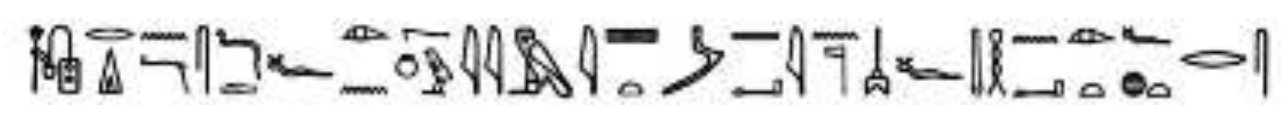

$s \bar{s} R d i$-ns ${ }^{11} d d, f i r . n .(i)$ nwy $(, j)$

mist. (i) mi"

in ntr wd f $m d w$. (i) hn' ir.t $(y), f(y)$ ht r,s

"Scribe Rediness says I have constructed my tomb by my own means, it is the God who will judge who does anything against it" ${ }^{51}$

The lintel inscriptions:

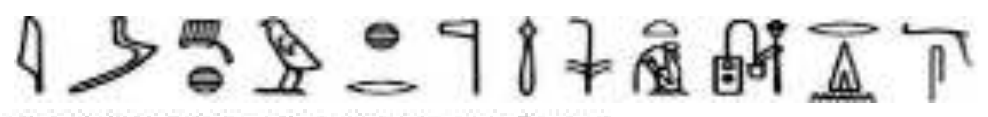

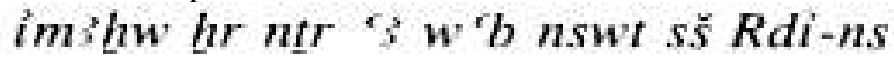

"The revered one before the great God,the royal priest Rediness.

The exterior of the niche, left thickness texts:

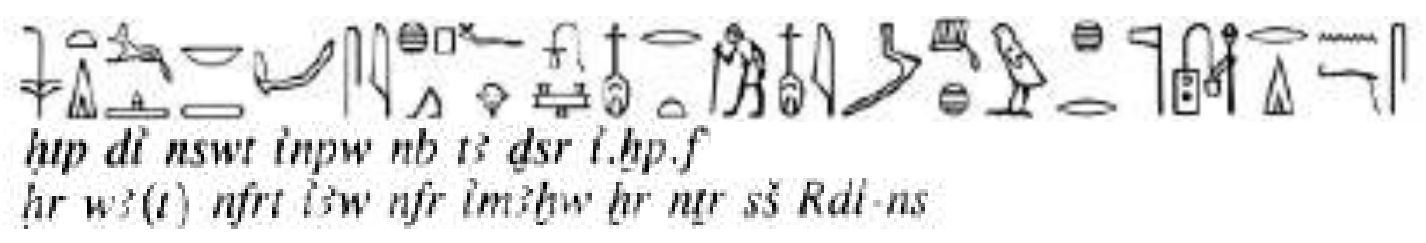

"A gift which the King and Anubis Lord of the sacred land give, that he might travel upon the beautiful way, having attained a ripe old age, one revered before the God, scribe Rediness". ${ }^{2}$

The exterior of the niche, right thickness texts:

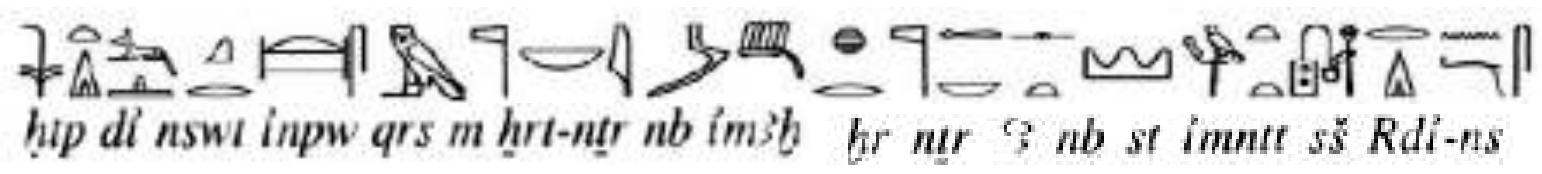

"A gift which the King and Anubis give, a burial in the necropolis, a possessor of veneration, before the great God, Lord of western desert. The scribe Rediness ${ }^{53}$.

The two jamb's inscriptions show how the scribe Rediness was keen to protect his tomb from any evil, while the niche's exteriors were devoted to offering formula.

\section{False door aspects during the Middle Kingdom}

From the early Middle Kingdom, false door was mainly of an offering stela ${ }^{54}$ which was mostly decorated with the $w \underline{d} 3 . t$ "eyes, of God Horus. ${ }^{55}$ The eyes' main purpose was to enable the deceased to look out of the spirit-world into the tomb-chapels to see visitors of the tomb, ${ }^{56}$ and to witness the progress of funerary services performed ${ }^{57}$

During the Middle Kingdom, tomb chapels can have more than one false door for the deceased. This period's false doors were of identical design and had distinctive stylistic features; like the identification of the deceased with God Osiris, ${ }^{58}$ the two $w \underline{d} 3 . t$ "eyes on the lintel, and the unusual tall palm leaves on top of the torus molding. In addition, they were characterized by depicting some alabaster jars $\vec{\Gamma},{ }^{59}$ with sacred oils on the inner jambs, ${ }^{60}$ and the representation of the two forked legs supporting the offering table. Some false doors did not follow the Old Kingdom regulation for the west location in the tomb chapel, they were located on non-west walls.

The false door of "Ankhef", commander and overseer of the fields, stored in Cairo Museum, will be the case study for Middle Kingdom. 

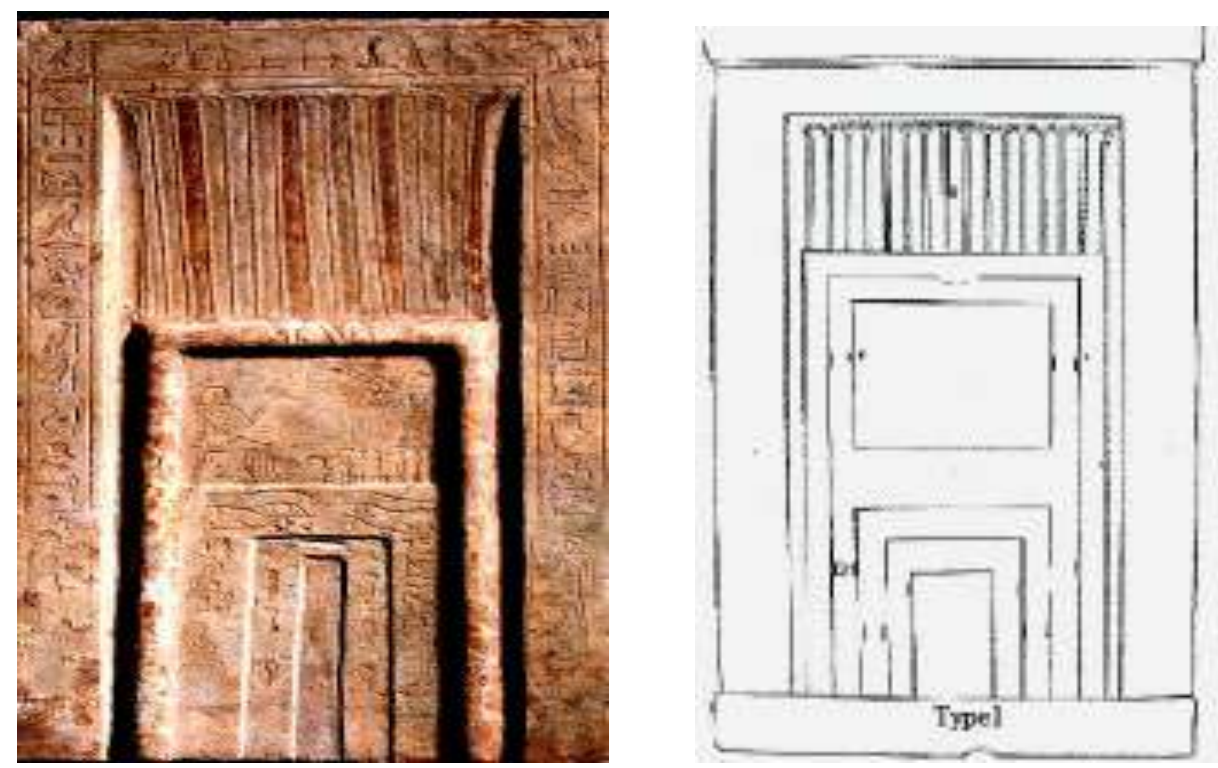

Fig. (4)The False door of"Ankhef”: Jacobus.V.D. (2006) "False-door stela of Ankhef," in Objects for Eternity: Egyptian Antiquities from the W. Arnold Meijer Collection, p.42

The False door stelae of "Ankhef" from the cemetery at Ehnasya el-Medina, ${ }^{61}$ is one of twenty excavated false doors. ${ }^{62}$ This cemetery false doors were attached to the funerary chambers' western wall, forming part of a small independent chapel. ${ }^{63}$ Pérez Die in his research divided the twenty false doors to four types; "Ankhef" false door was classified to one type shown above, this was characterized by its simplicity. However, the other three types are of different; torus molding height, number of jambs, and the dimension of the central niche.

The false door is completely framed by an inscription band; starts in the upper center, and then divides into two symmetrically arranged texts, each containing an offering formula. ${ }^{64}$ The central panel was displayed by the usual funerary meal scene, decorated with a seated figure of the deceased, putting his left arm on his chest, and the right arm is extended towards an offering table. ${ }^{65}$ The" $w \underline{d} 3 . t$ "eyes "are carved on the cross bar above the central niche, through which the deceased looks out to within the world of the living. ${ }^{66}$ The inner jambs are carved by six alabaster vessels containing the seven sacred oils, the outer jambs show the deceased seated on the left facing his wife who smells a lotus on the right. ${ }^{67}$ Traces of paints are still visible on the cornice leaves. ${ }^{68}$

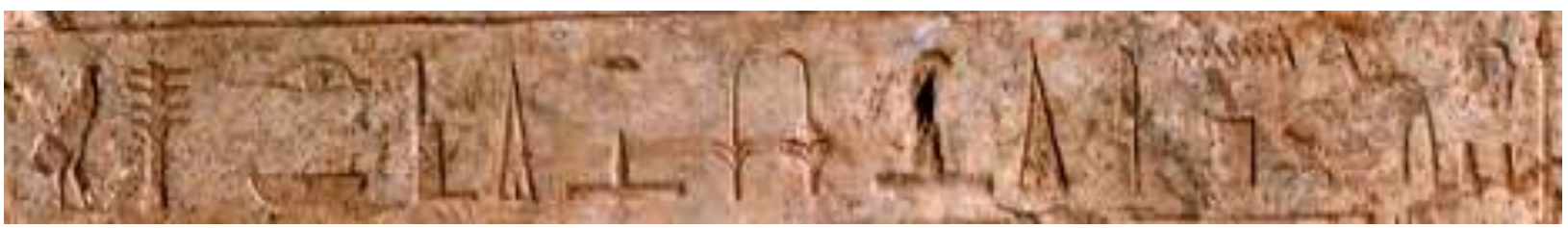

The upper central frame shows the offering formula, divided to two section; the one on the right shows the offering formula dedicated to God Anubis, while the one on the left is dedicated to God Osiris.

\section{False door aspects during the New Kingdom}

During the new kingdom, false door was rarely located in the tomb-chapel, and was preferably placed on one of the two side-walls of the transverse hall, most frequently by the left southern one. ${ }^{69}$ The $18^{\text {th }}$ Dynasty invention was the decoration of the false door stela with religious symbols, ${ }^{70}$ the most common symbol: the "šn": symbol of eternity, between the two " $w \underline{d} 3 . t$ " eyes. ${ }^{71}$

After the 'Amarna period, the false door disappeared in Theban Necropolis, and a new form appeared. This is the false door stela, ${ }^{72}$ which was characterized with two representation fields; the tomb owner is in the upper field addresses the Gods, and the mortuary cult is represented in the lower field. ${ }^{73}$ The main feature of the New Kingdom false doors was the inscribed text below the scene.

The False door stela of "Horemhat" is our case study for the New Kingdom false doors. The monumental object is among the collections of the Egyptian Museum of Turin. It is a limestone round-topped stela of the priest " $h r m h t^{\prime}$ " dating to the $18^{\text {th }}$ Dynasty, ${ }^{74}$ The lunette shows two " $w \underline{d} 3 . t$ " eyes flanking a " $s n$ " ring. There are two registers; the upper shows pictorial depictions, while the lower is inscribed with horizontal Hieroglyphic texts. ${ }^{75}$

It represents the priest seated, holding and smelling a lotus blossom 'symbol of rebirth'. His brother " $m n w$ " follows him while standing before two standing ladies; his wife who is pouring a libation with her right hand, and holding a cloth in her left, and her daughter is next to her. ${ }^{76}$ 


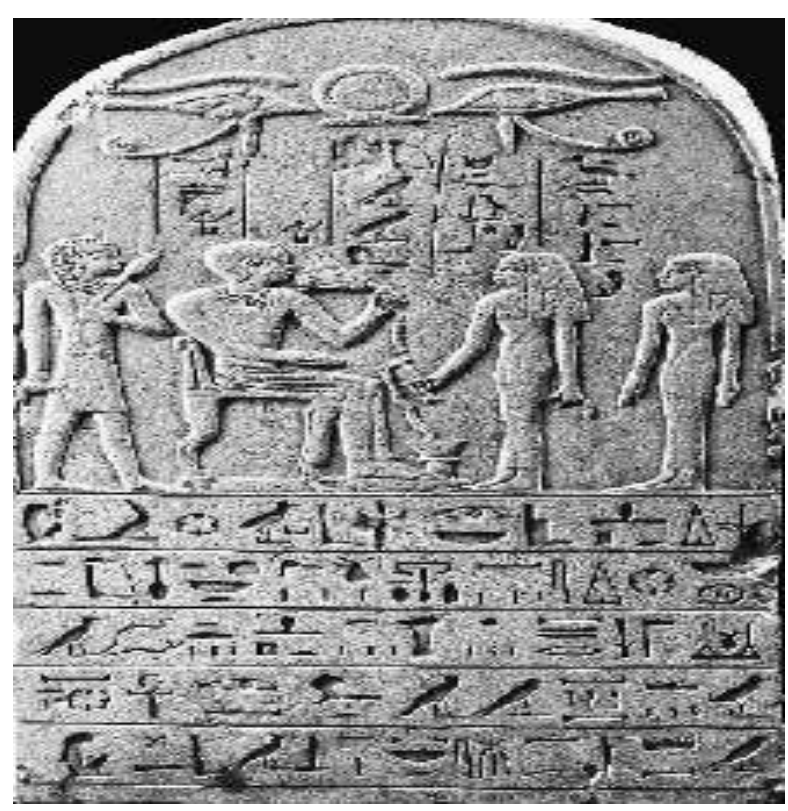

Fig. (5) Stela of Hermhat, Satzinger.H,Stefanović.D.(2009),the Stela of Horemhat at Turin, CdE (134),p.89

\section{Conclusion}

In Ancient Egyptian thought, the false door was a main element to ensure and satisfy the deceased's needs deceased in the netherworld, to guarantee the same standard of life he once had during his life time. This element's significance in the tomb's western wall leads to the conclusion that any change on the false door was due to a change in the interpretation of its cultic meaning, or due to architectural considerations. The table below shows the main concept of the false door did not change, while other features did.

\begin{tabular}{|c|c|c|c|}
\hline & Old Kingdom & Middle Kingdom & New Kingdom \\
\hline The concept & $\begin{array}{l}\text { - The gate between the living } \\
\text { world and the underworld. } \\
\text { - The spot where the deceased } \\
\text { could come forth to receive } \\
\text { offerings. }\end{array}$ & $\begin{array}{l}\text { - Offering stele. } \\
\text { - Identification of the tomb } \\
\text { owner }\end{array}$ & - Offering stele. \\
\hline $\begin{array}{l}\text { The offering } \\
\text { formula }\end{array}$ & $\begin{array}{l}\text { - The most important feature of } \\
\text { the door, re- presented on the } \\
\text { door panel. }\end{array}$ & $\begin{array}{l}\text { - The offering formula was } \\
\text { inscribed on the false } \\
\text { doors jambs and panel. }\end{array}$ & $\begin{array}{l}\text { - First line of the text, } \\
\text { below the figures. }\end{array}$ \\
\hline The design & $\begin{array}{l}\text { - Palace Façade. } \\
\text { - Normal decorated door. }\end{array}$ & $\begin{array}{l}\text { - Framed by an } \\
\text { inscription band, starts } \\
\text { in the upper center, and } \\
\text { then divided into two } \\
\text { symmetrically arranged } \\
\text { texts, each containing an } \\
\text { offering formula. }\end{array}$ & $\begin{array}{l}\text { - Mostly round topped } \\
\text { stele, where the scene is } \\
\text { followed by the text } \\
\text { lines. }\end{array}$ \\
\hline Location & $\begin{array}{l}\text { - West wall of the Tomb- } \\
\text { Chapel in Mastaba Tombs. } \\
\text { - West and non-west wall in } \\
\text { cut-rock Tombs. }\end{array}$ & West and non-west wall. & West and non-west wall. \\
\hline $\begin{array}{l}\text { The Decoration } \\
\text { features }\end{array}$ & $\begin{array}{l}\text { - A monolith form, absence and } \\
\text { presence of the cavetto } \\
\text { cornice and the Torus } \\
\text { molding was the main } \\
\text { difference. }\end{array}$ & $\begin{array}{l}\text { - The Udjat eyes on the } \\
\text { cross bar. } \\
\text { - The seven sacred oils. } \\
\text { - Smelling a blossom of } \\
\text { Lotus. }\end{array}$ & $\begin{array}{l}\text { - The Shen symbol } \\
\text { between the Udjat eyes } \\
\text { on the cross bar. } \\
\text { - Separating the text from } \\
\text { the figures. }\end{array}$ \\
\hline
\end{tabular}

Although the motifs on the false doors were mainly identical; the inscriptions on the false doors and their location were varied during different phases. The variations may suggest false doors -in private tombs- have aspects rather than a religious purpose. Some studies suggested; if the false door had a non-religious function, it will be in twofold: social status symbol, or a grave marker. Moreover, the equipping of rock-cut tombs in the provinces with more than one decorated false door demonstrated the tomb owners' fortune, social status, and his post in the social administration. Therefore, the deceased's name and titles were essential in false door's decoration. 
Other theories suggested the false doors were mainly of religious function. This is due to the offering formula dedicated to the Gods, and the religious symbols related to the offering rituals, such as the two "w $\underline{d}_{3} . t$ "'eyes, the "šn" ring, the seven sacred oil, and the smelling lotus scenes employed to decorate the false doors.

As a conclusion, false doors had a religious and a non-religious function as well. Religious function to emphasize the importance of the deceased name as commemorative, and non- religious to keep a connection through this door between the living world and the netherworld.

\section{Endnotes}

${ }^{1}$ Takenoshita, J. (2011),"When the Living met the Dead: The Social Functions of False Doors in Non-Royal Funerary Culture with references to examples from the First Intermediate Period and Middle Kingdom": A Thesis submitted to The University of Birmingham for the degree of Master of Philosophy, Institute of Archaeology and Antiquity College of Arts and Law, The University of Birmingham, p.1.

${ }^{2}$ Haeny, G. (1984), ’Scheintür", LÄ (V), col.566.

${ }^{3}$ Faulkner (1962), A concise Dictionary of Middle Egyptian, Oxford, p.145.

4 Erman A., Grapow H. Wörterbuch der aegyptischen Sprache Bd. I-V (1926-1931), VI (1950), VII (1971),Belegstellen I-V,Wb(II),p.397.

${ }^{5}$ Ibid, p.403.

${ }^{6}$ Ibid, p.147.

${ }^{7}$ Haeny, op.cit, col.563.

${ }^{8}$ Lekov,T.(2005),Ancient Egyptian notion of Ka according to the Pyramid texts ,JES (1),p.19.

9 Ćwiek, A.(2003), Relief decoration in the Royal funerary complexes of the Old Kingdom, PhD Thesis ,Warsaw University,p.331.

${ }^{10}$ Jacobus,V.D., (2006) "False-door stela of Ankhef," in Objects for Eternity: Egyptian Antiquities from the W. Arnold Meijer Collection ,p41.

11 Ibid

12 Ibid

${ }^{13}$ Takenoshita, op.cit, p.6.

${ }^{14}$ Ibid

15 Ibid

${ }^{16}$ Snape, S., (2011), Ancient Egyptian Tombs, the culture of life and death, Oxford, p.27.

${ }^{17}$ Ibid, 28.

${ }^{18}$ Takenoshita, op.cit, p.94.

${ }^{19}$ Badawy, A. (1969), Illusionism in Egyptian Architecture,SAOC(35),p.16.

${ }^{20}$ Źabkar.L (1969), A Greco-Egyptian funerary Stela,SAOC(35)p.106.

${ }^{21}$ Willockx.S.(2007),Magic and religion Ancient Egypt,PartII,p.48: https://www.academia.edu/6774976/Amentet_Andjeti_and_Anubis_Three_Ancient_Egyptian_Gods.last updated27/12/2014

${ }^{22}$ Bolshakov, A., (2001), Osiris in the Fourth Dynasty again, The False door of Inty, MFA31.781,BMHB , Supplément2001,Budapest,p.65.

${ }^{23}$ Fisher.H. (1976), Some early monuments of Busiris, in the Egyptian Delta, MMJ (11), p.5.

${ }^{24}$ Tomich.A. (2011), Changes in the hth di nsw formula in the late middle Kingdom and second Intermediate period,ZÄS(138),p.20.

${ }^{25}$ Faulkner.R. (1941), Reviews and notices of recent publications, JEA (27),p. 166.

${ }^{26}$ El-Enany.K.(2008), Stèle privée de la fin du moyen empire découverte à Karnak,Le Caire, Musée Egyptien JE37515,BIFAO(108),p.101-102.

${ }^{27}$ Reisner.G.A.(1932), The position of early grave Stelae, studies presented toF.LL.Griffith,p.325: http://gizapyramids.org/pdf_library/reisner_griff_stud_1932.pdf

28 Ibid.

${ }^{29}$ Takenoshita, op.cit, p.7.

${ }^{30}$ Cherpion.N. (1982), La Fausse porte D;Itefenen et Peretim au muse du Caire, BIFAO 82p.127.

${ }^{31}$ Ibid.

32 Ibid.

${ }^{33}$ Der Manuelian.P. (1998), A case of prefabrication at Giza? The false door of Inti, JARCE (35), p.116.

${ }^{34}$ Strudwick.N. (1985), The Administration of Egypt in the Old Kingdom, London, p.15.

35 Ibid.

${ }^{36}$ Ibid, p. 17.

${ }^{37}$ Ibid.

38 Ibid.

${ }^{39}$ Brovareski. E. (2004), False doors \&history: The sixth dynasty, Prague, p.71. 
${ }^{40}$ Kanawati.N,Hassan, A. (1996), The Teti cemetery at Saqqara,The Australian Centre for Egyptology, reports (8),Sydneymp.19.

${ }^{41}$ Ibid.

${ }^{42}$ Kuraszkiewicz, K. (1998), False door Stele of Meref-Nebef, PAM (10), p.105.

${ }^{43}$ Provenance: Giza, tomb G 5032. 1914, excavated by the Harvard University-Museum of Fine Arts Expedition, assigned to the MFA by the government of Egypt; shipped 1921. (Accession Date: March 1, 1921).

${ }^{44}$ Der Manuelian. op.cit, p.75.

${ }^{45}$ Ibid, p.56.

${ }^{46}$ The false door is among a collection of 46 False doors in the Museum of Fine Arts, Boston: http://www.mfa.org/last updated28/11/2014.

${ }^{47}$ Der Manuelian, op.cit, p.59.

${ }^{48}$ Ibid, p.75.

${ }^{49}$ Ibid, p.71.

${ }^{50}$ Ibid, p.63.

${ }^{51}$ Ibid, p.65.

${ }^{52}$ Ibid, p.64.

${ }^{53}$ Ibid, p.66.

${ }^{54}$ Takenoshita, op.cit, p.63.

${ }^{55}$ Ibid, p.23.

${ }^{56}$ Blackman.A. (1916), The Ka-house and the Serdab, JEA (3), p.252.

${ }^{57}$ Ibid.

${ }^{58}$ Pérez Die.M. (2010),The False Door at Herakleopolis Magna(I)Typology and Iconography, CASAE (4),p.372.

${ }^{59}$ Satzinger.H. (2009), Offerings for the Kas of six ladies (British Museum Stela No.1678," Journal of Classical Studies Matica Srpska (11) p.32.

${ }^{60}$ Jacobus.V.D. (2006) "False-door stela of Ankhef," in Objects for Eternity: Egyptian Antiquities from the W. Arnold Meijer Collection, $\mathrm{p} 43$.

${ }^{61}$ Modern name of Herakleopolis Magna ancient capital of Egypt during the1st Int. period. Spanish excavations started in this area in1966 discovering the Ancient Necropolis of the city.

${ }^{62}$ Pérez Die studied the 20 false doors typologically and ichnographically in his research dedicated to Brovareski in CASAE (40).

${ }^{63}$ Pérez Die, op.cit, p.362.

${ }^{64}$ Ibid, p43.

${ }^{65}$ Ibid.

${ }^{66}$ False-door stela of Ankhef, p.43.

${ }^{67}$ Ibid.

${ }^{68}$ Pérez Die, op.cit, p. 358.

${ }^{69}$ Salvador,C. (2014),From the realm of the dead to the house of the God: To the New Kingdom appeals to the living in context at Thebes: Current research in Egyptology2013,Oxford,p.157.

${ }^{70}$ Myśliwiek.C (1985), Eighteenth Dynasty before the Amarna Period, Leiden, p. 26.

${ }^{71}$ El-Enany, K., op.cit, p.101.

${ }_{72}^{72}$ Assmann.J. (2005), Death and salvation in Ancient Egpt,Cornell University,p.211.

${ }^{73}$ Ibid, p.212.

${ }^{74}$ Satzinger, H., Stefanović, D. (2009), The Stela of Horemhat at Turin, CdE(134), p.88.

${ }^{75}$ Ibid.

${ }^{76}$ Ibid, p. 90.

\section{دراسة لتطور مفهوم الباب الوهمي}

يعد الباب الوهمي من العناصر الرئيسية التي حرص المصري القديم على تو افرها بمقبرتها، حيث بعد الباب الوهمي بمثابة البو ابة التي لئي

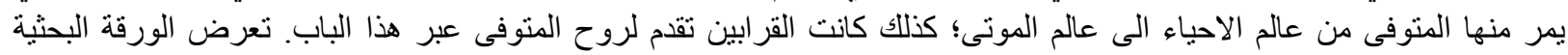

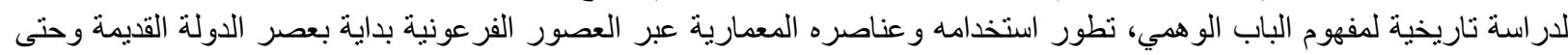

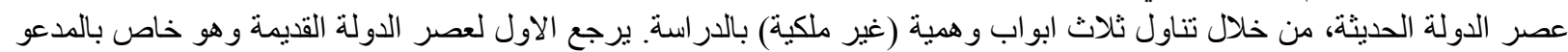

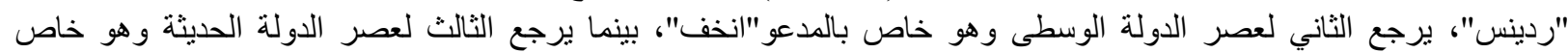

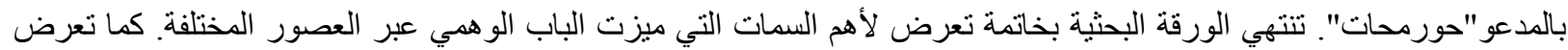

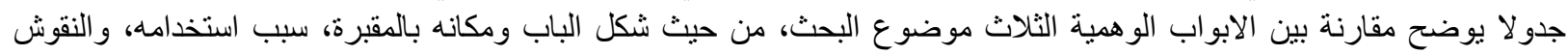
الخاصة به من حيث صيغة تقديم القر ابين وسماته الفنية الاخرى. الكلمات الدالة: باب و همى، غير ملكى، حجر جيرى، جر انيت وردى، مقصورة، معبد جنائزى 